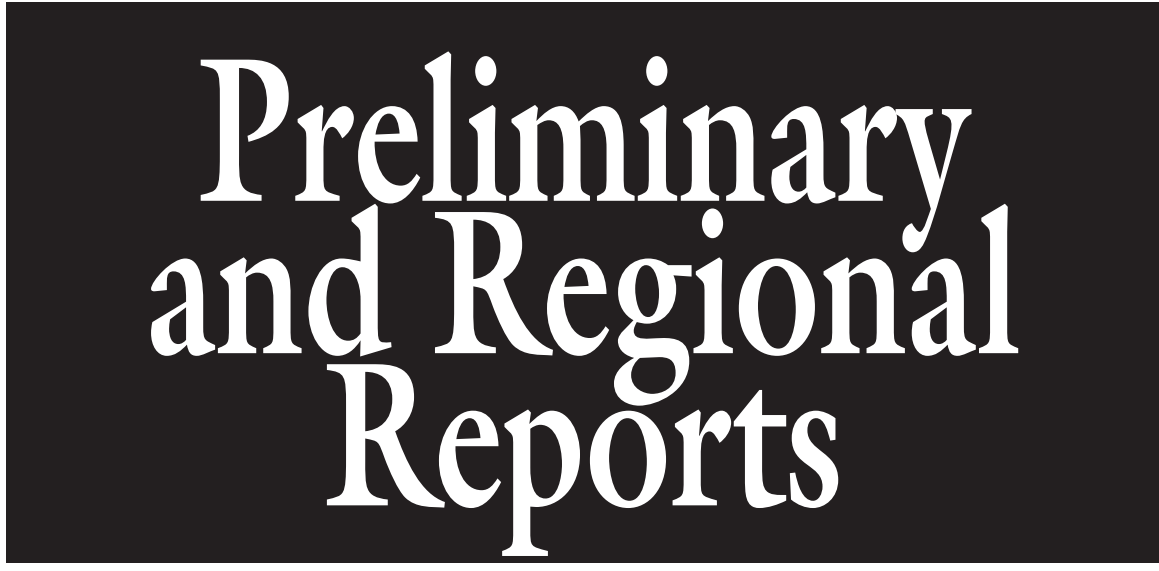

\section{Vegetative Establishment Rate and Stolon Growth Characteristics of 10 Zoysiagrasses in Southern Europe}

\author{
Antonio Pompeiano ${ }^{1}$, Nicola Grossi, and Marco Volterrani
}

ADDITIONAL INDEX WORDs. coverage, growth analysis, stolon growth rate, biometric traits, digital image analysis, modular turfgrass system

SUMMARY. In today's climate, in which economic and environmental sustainability has to be ensured, it is important to promote the use of grass species that require minimal maintenance inputs. The superior heat and drought tolerance of zoysiagrass (Zoysia spp.) makes it an excellent choice for Mediterranean areas. A study was conducted to evaluate the establishment rate from vegetative plugs of 10 zoysiagrass genotypes (i.e., species and cultivars). Stolon growth rate, establishment rates, biometric traits, and winter color retention were measured. Establishment rate was measured using digital image analysis, and the data were fit to a sigmoid variable slope model.

Zoysiagrass genotype significantly affected turf coverage during the establishment. At 140 days after plugging, 'DALZ0101' and 'Zenith' had significantly more turfgrass coverage, while 'Emerald', 'HT-210', 'Meyer', and mascarene grass (Zoysia pacifica) had the lowest coverage. Differences in total stolon length and growth rate were observed among the genotypes and for all stolon growth parameters. Japanese lawn grass (Zoysia japonica) had higher values compared with manilagrass (Zoysia matrella). A distinct trend in days to maintained $\mathbf{5 0 \%}$ color retention (Days ${ }_{50}$ ) was observed in this study on the winter color retention of genotypes. Differences in color retention within japanese lawn grass cultivars were observed with 'Victoria' retaining color longer than 'DeAnza' and 'El Toro' (77.6, 57.8, and 57.2 Days 50 , respectively) and better than 'Meyer'. Japanese lawn grass cultivars exhibited poor color retention (50.3 Days $_{50}$ ) compared with manilagrass cultivars (79.3 Days 50 ).

W ithin the European Union, there is an increasing attention to explore and identify alternative grass species that will use less natural resources and be more sustainable in their fertilizer and pesticide requirements. Turfgrass researchers and extension specialists both agree that zoysiagrass is a wise choice for the transition zone (the temperate Mediterranean area lies in this zone) and is far

Centre for Research on Turfgrass for Environment and Sports (CeRTES), University of Pisa, Via San Michele degli Scalzi, 2, 56124 Pisa, Italy

${ }^{1}$ Corresponding author. E-mail: apompeiano@agr.unipi.it. more forgiving for reduced inputs than bermudagrass (Cynodon dactylon) and cool-season grasses (Fry et al., 2008;
Patton, 2007). It is valued to be a lowinput sustainable turf, and it continues to increase in popularity in the U.S. transition-zone environments (Lyman et al., 2007).

Zoysia, recognized to consist of 11 species, is naturally distributed throughout the Pacific Rim and has been used since ancient times as an ornamental groundcover, but only three species have been imported and grown in the United States as turfgrass since its introduction; these are japanese lawn grass and manilagrass (both often are referred to as zoysiagrass) and, to a more limited extent, mascarene grass (Forbes and Ferguson, 1947). Zoysiagrass, as a warm-season turfgrass characterized by the Hatch-Slack photosynthetic pathway $\left(\mathrm{C}_{4}\right)$, has an optimum growth temperature of 27 to $35^{\circ} \mathrm{C}$ - which is $\approx 10{ }^{\circ} \mathrm{C}$ higher than $\mathrm{C}_{3}$ plants (Leegood, 1993) - and in the transition zone, it has shown to actively grow in the summer months.

Zoysiagrass develops a uniform, low-growing, high-quality turf in full sun and partial shade conditions (Trappe et al., 201la), providing a dense, lush, and excellent surface for golf course fairways, tees and bunker faces with clean, tight lies. It forms a rigid turf (Turgeon, 1991) with a superior load-bearing capacity (Erusha et al., 1999) because of tissue rigidity and stiffness. It has excellent wear tolerance and recuperative potential from injury caused by concentrated traffic (Youngner, 1961a). Once established, zoysiagrass will crowd out most weeds (Diesburg, 2001; Richardson and Boyd, 2001). Excellent heat, drought, salinity, and pest tolerance compared with cool-season turfgrasses has been observed (Beard, 1973; Du et al., 2008; Marcum and Murdoch, 1990; Marcum et al., 1995), resulting in fewer inputs and lower maintenance costs (Fry et al., 2008). Differences in divot injury recovery were investigated among zoysiagrass

\begin{tabular}{llll}
\hline $\begin{array}{l}\text { Units } \\
\begin{array}{l}\text { To convert U.S. to SI, } \\
\text { multiply by }\end{array}\end{array}$ & U.S. unit & SI unit & $\begin{array}{l}\text { To convert SI to } \\
\text { U.S., multiply by }\end{array}$ \\
\hline 0.3048 & $\mathrm{ft}$ & $\mathrm{m}$ & 3.2808 \\
2.54 & inch(es) & $\mathrm{cm}$ & 0.3937 \\
25.4 & inch $(\mathrm{es})$ & $\mathrm{mm}$ & 0.0394 \\
0.3937 & inch/inch & $\mathrm{cm} \cdot \mathrm{cm}^{-2}$ & 2.54 \\
6.4516 & inch & $\mathrm{cm}$ & 0.1550 \\
1 & meq $/ 100 \mathrm{~g}$ & $\mathrm{cmol}^{2} \cdot \mathrm{kg}^{-1}$ & 1 \\
4.3942 & $\mathrm{oz} / \mathrm{inch}^{2}$ & $\mathrm{~g} \cdot \mathrm{cm}^{-2}$ & 0.2276 \\
1.7300 & $\mathrm{oz} / \mathrm{inch}^{3}$ & $\mathrm{~g} \cdot \mathrm{cm}^{-3}$ & 0.5780 \\
33.9057 & $\mathrm{oz} / \mathrm{yard}^{2}$ & $\mathrm{~g} \cdot \mathrm{m}^{-2}$ & 0.0295 \\
$\left({ }^{\circ} \mathrm{F}-32\right) \div 1.8$ & ${ }^{\circ} \mathrm{F}$ & ${ }^{\circ} \mathrm{C}$ & $\left(1.8 \times{ }^{\circ} \mathrm{C}\right)+32$ \\
& & &
\end{tabular}


cultivars (Karcher et al., 2005; Trappe et al., 201 lb), shade and traffic tolerance (Trappe et al., 201la), as well as clipping yield (Trappe et al., 2009).

According to early reports, japanese lawn grass has been identified as the most low-temperature hardy among the warm-season grasses and has shown better spring green-up and less winter injury in comparison with manilagrass (Daniel, 1955; Forbes and Ferguson, 1947). Additionally, cultivars of japanese lawn grass with commercial seed availability have shown less winter injury than cultivars of japanese lawn grass and manilagrass available only as vegetative propagules (Patton and Reicher, 2007). Zoysiagrass for these characteristics has a unique niche in the northern transition zones, where bermudagrass fails because of its inability to survive harsh winters.

A distinct drawback to the use of zoysiagrass is the slow establishment rate (Busey and Myers, 1979), which increases costs and increases the likelihood of water and wind soil erosion. Additionally, the lack of improved seeded cultivars has dimmed its popularity during the years. Many experiments were carried out since late 1950s to fathom out the best cultural practices to hasten establishment rate. Nitrogen fertilization has been well documented to increase shoot growth in bermudagrass, but it has inconsistent effects on zoysiagrass establishment (Carroll et al., 1996; Dunn, 1991; Fry and Dernoeden, 1987; Richardson and Boyd, 2001). However, since first reports, japanese lawn grass cultivars have been reported to be more rapid during the establishment phase than manilagrass (Beard, 1973; Forbes and Ferguson, 1947; McCarty, 2001; Patton et al., 2007; Turgeon, 1991), but primarily cultivar selection influences establishment rate (Dunn, 1991; Patton et al., 2007; Sifers et al., 1992a). To better understand the differences between genotypes, growth analysis has evidenced that high stolon growth rate of quickestablishing genotypes is due to a higher proportion of dry weight partitioned to stems instead of leaves (Patton et al., 2007).

Another limiting factor is winter dormancy, a temporary suspension of visible growth of any plant structure containing a meristem (Lang et al., 1987). Discoloration, enhanced by stronger light intensity (Youngner, 1961b), starts when the average minimum air temperature for $15 \mathrm{~d}$ (consecutive) is below $15{ }^{\circ} \mathrm{C}$, followed by termination of shoot growth when below $\approx 10{ }^{\circ} \mathrm{C}$ (Wei et al., 2008) significant differences among species and cultivars are known. Cultural practices have been used to extend the winter color retention of zoysiagrass in late fall or early spring, showing different levels of success when applying late-season nitrogen or iron (Dunn et al., 1993; Gibeault et al., 1997) and overseeding (Hunt and Wen Cai, 1993; Hurley et al., 1989). Genotype interaction with winter color retention could be an important trait to consider to prolong the aesthetic function.

In previous research carried out in central and northern Italy (Croce et al., 2001; De Luca et al., 2008; Miele et al., 2000; Pompeiano et al., 2008; Volterrani et al., 1997), zoysiagrass showed good adaptation, being the slowest in entering dormancy and fastest in spring green-up.

Relatively little is known about the dynamics of cold acclimation of zoysiagrass before exposure to low but nonfreezing temperatures. Large differences in response to low temperatures and winter injury between species and cultivars of zoysiagrass are known (Patton and Reicher, 2007), and different behavior among them are expected in the way they decline, go dormant, and lose color.

The aim of this study was to evaluate 10 genotypes of zoysiagrass established from plugs, assessing differences in establishment rate, winter

Table 1. Zoysiagrass species and cultivars evaluated for vegetative establishment rate and stolon growth characteristics, and their typical establishment method.

\begin{tabular}{lllc}
\hline Common name & \multicolumn{1}{c}{ Zoysia species } & $\begin{array}{c}\text { Cultivar/ } \\
\text { genotype }^{\mathbf{z}}\end{array}$ & $\begin{array}{c}\text { Establishment } \\
\text { type }^{\mathrm{y}}\end{array}$ \\
\hline Japanese lawn grass & Z. japonica & DeAnza & Vegetative \\
Japanese lawn grass & Z. japonica & El Toro & Vegetative \\
Japanese lawn grass & Z. japonica & Meyer & Vegetative \\
Japanese lawn grass & Z. japonica & Victoria & Vegetative \\
Japanese lawn grass & Z. japonica & Zenith & Seeded \\
Hybrid zoysiagrass & Z. japonica $\times$ Z. pacifica & Emerald & Vegetative \\
Hybrid zoysiagrass & Z. japonica $\times$ Z. pacifica & HT-210 & Vegetative \\
Manilagrass & Z. matrella & DALZ0101 & Vegetative \\
Manilagrass & Z. matrella & Zeon & Vegetative \\
Mascarene grass & Z. pacifica & - & Vegetative \\
\hline
\end{tabular}

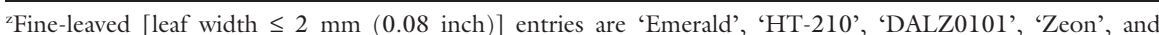
mascarene grass.

yall entries were established by vegetative plugs into plots for this study.

${ }^{x}$ Formerly $Z$. japonica $\times Z$. tennifolia (Forbes, 1962), now Z. japonica $\times Z$. pacifica (Anderson, 2000). color retention, and biometric traits in a Mediterranean area.

\section{Materials and methods}

Ten zoysiagrass genotypes ( $\mathrm{Ta}-$ ble 1) were evaluated at the Centre for Research on Turfgrass for Environment and Sports (CeRTES), University of Pisa, Italy, (lat. $43^{\circ} 40^{\prime} \mathrm{N}$, long. $10^{\circ} 19^{\prime}$ E, 6 m elevation) during Summer 2006. The study was conducted 10 modules (Integrated Turfgrass Richmond, VA) injection-molded from high-density polyethylene plastic with external dimension of $1.2 \mathrm{~m} \times 1.2 \mathrm{~m} \times$ $\mathrm{m}$, used in athletic field, golf 作 (Hurley, 2000). The bottom base is perforated, enabling drainage and gas exchange up through the root zone. 列 pensate depth differes ameter $2.0-3.4 \mathrm{~mm}$ ) as drainage layer and $8.0 \mathrm{~cm}$ of volcanic sand as rootzone medium (25\% lapillus and $75 \%$ pumice), with a $\mathrm{pH}$ of $7.0,0.95 \mathrm{~g} \cdot \mathrm{cm}^{-3}$ bulk density, and $30 \mathrm{cmol} \cdot \mathrm{kg}^{-1}$ cation exchange capacity. A complete slowrelease nitrogen fertilizer $(20 \mathrm{~N}-2.2 \mathrm{P}-$ $6.6 \mathrm{~K}-1.2 \mathrm{Mg}$ ) was incorporated into the soil at a rate of $25 \mathrm{~g} \cdot \mathrm{m}^{-2}$, and finally the plots were leveled before planting. Following establishment, the fertilization program included an application of $10 \mathrm{~g} \cdot \mathrm{m}^{-2} \mathrm{~N}$ from diammonium phosphate $(18 \mathrm{~N}-20.1 \mathrm{P}-0 \mathrm{~K}-2 \mathrm{~S})$ on 1 Aug. The plot layout was a randomized completed block design with four replications. Individual plots, four for Management System; GreenTech, modules) of fine gravel (particle di- 
each module, were $54.5 \mathrm{~cm} \times 54.5 \mathrm{~cm}$. One $6.0-\mathrm{cm}$-diameter plug was transplanted from mature ( $>5$ years) zoysiagrass turfs-as well as the seeded genotype (Volterrani et al., 2008), into the center of each plot on 30 May. Irrigation was applied three times daily during the first $10 \mathrm{~d}$ to promote establishment, and then as needed to prevent wilting and heat stress. No pesticides were applied, and competing weeds were manually removed during establishment. In addition, to avoid genotype by mowing interactions, the plots were not mowed since the optimum mowing height varied by genotype (Higgins, 1998; Unruh et al., 2006).

Zoysiagrass growth rate was evaluated weekly using digital image analysis techniques (Richardson et al., 2001) to quantify the percent green turf cover for each plot. Pictures were analyzed individually by SigmaScan Pro (version 5.0; Systat Software, San Jose, CA). To selectively identify zoysiagrass green leaves, a hue range from 45 to 100 and a saturation range from 0 to 100 were adopted after preliminary work on zoysiagrass. In addition, to increase accuracy and limit the negative interaction of lapillus that would overestimate the coverage, overlay filters were used. Inside each plot a $12.0-\mathrm{cm} \times 3.0-\mathrm{cm}$ sign was placed for calibration and rescaling manually the pictures by converting raw pixel coordinates into a specified measurement unit $\left(\mathrm{cm}^{2}\right)$. The coverage was recorded until $140 \mathrm{~d}$ after plugging (DAP), reaching a plateau because of plant growth ceased.

For each plot, on 20 June, four stolons were selected, and weekly measurements of lateral spread were collected, marking the tip with colored tailor pins, till each stolon reached the border of its plot. The mean and total (of four) stolon length $56 \mathrm{DAP}$, and the stolon growth rate (by dividing the maximum length of each stolon by days) were determined from 49 to 56 DAP (when the growth rate was maximum).

On 1 Nov. 2006, plots were sampled with a core sampler $(6.0-\mathrm{cm}$ diameter $\times 9.0-\mathrm{cm}$ height) to determine the following biometric traits: stolon/ rhizome internode diameter, stolon/ rhizome internode length, stolon/rhizome density, and stolon/rhizome dry biomass. Stolons and rhizomes were included as a unique tissue because of difficulties encountered in separating according to their growth habit. In addition, after 17 Oct., plots were visually rated for winter color retention on a $10-\mathrm{d}$ schedule using a scale of $0 \%$ to $100 \%$ (with $100 \%$ being full retention- $0 \%$ completely brown) until green winter color of the genotypes reached zero (30 Jan.). A nonlinear regression analysis for this parameter was performed using this sigmoid variable slope model: \{green turf cover $(\%)=$ bottom $+(100-$ bottom $) /(1+10$ $\left[\left(\right.\right.$ Days $\left._{50}-X\right) \times$ slope $\left.\left.)\right]\right\}$, where bottom is the plateau in percent and $X$ is number of days after 17 Oct., and the slope parameter defines the steepness of the curve. Parameter estimates were used to calculate confidence intervals (95\%) for number of days withheld until each genotype reached $50 \%$. At each green color retention percentage, genotypes were considered significantly different if their confidence

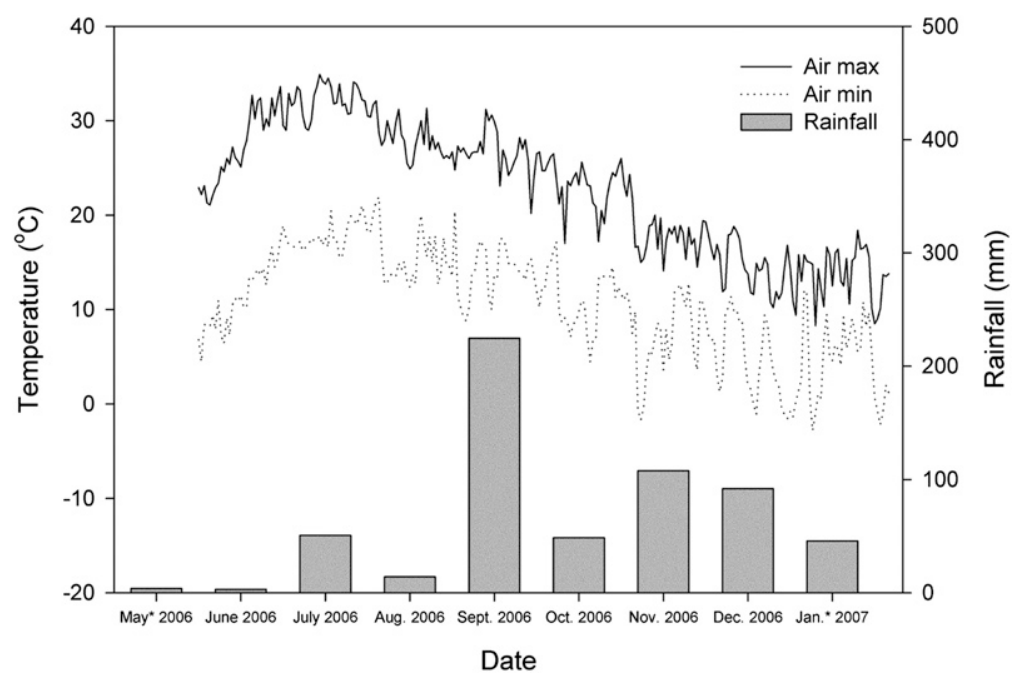

Fig. 1. Maximum and minimum daily temperature recorded at $2 \mathrm{~m}(6.6 \mathrm{ft})$ above soil surface during the whole growth season and monthly rainfall precipitation.

${ }^{*}$ May and January values are limited according to the trial time; $\left(1.8 \times{ }^{\circ} \mathrm{C}\right)+32={ }^{\circ} \mathrm{F}$, $1 \mathrm{~mm}=0.0394$ inch .

Table 2. Coverage at 35, 70, and $140 \mathrm{~d}$ after plugging (DAP), total stolon length at $56 \mathrm{DAP}$, and stolon growth rate of the zoysiagrass cultivars and species studied.

\begin{tabular}{|c|c|c|c|c|c|}
\hline Cultivar or species & $\begin{array}{l}35 \text { DAP } \\
\text { coverage } \\
\left(\mathrm{cm}^{2}\right)^{\mathrm{z}}\end{array}$ & $\begin{array}{c}70 \text { DAP } \\
\text { coverage } \\
\left(\mathrm{cm}^{2}\right)\end{array}$ & $\begin{array}{l}140 \text { DAP } \\
\text { coverage } \\
\left(\mathrm{cm}^{2}\right)\end{array}$ & $\begin{array}{l}56 \text { DAP total } \\
\text { stolon length } \\
(\mathrm{cm})^{\mathrm{y}}\end{array}$ & $\begin{array}{c}\text { Stolon } \\
\text { growth rate } \\
(\mathrm{cm} / \mathrm{wk})^{\mathrm{x}}\end{array}$ \\
\hline 'DeAnza'w & $72 \mathrm{bc}^{\mathrm{v}}$ & $376 \mathrm{abc}$ & $1271 \mathrm{ab}$ & $20.2 \mathrm{~b}-\mathrm{e}$ & $6.3 \mathrm{~b}-\mathrm{f}$ \\
\hline 'El Toro' & $81 \mathrm{ab}$ & $408 \mathrm{abc}$ & $1188 \mathrm{abc}$ & $18.1 \mathrm{~b}-\mathrm{f}$ & 8.0 a-e \\
\hline 'Meyer' & $46 \mathrm{~d}$ & $180 \mathrm{c}$ & $558 \mathrm{c}$ & $9.2 \mathrm{f}$ & $2.6 \mathrm{f}$ \\
\hline 'Victoria' & $57 \mathrm{~cd}$ & $336 \mathrm{abc}$ & $1190 \mathrm{abc}$ & $17.7 \mathrm{c}-\mathrm{f}$ & $6.2 \mathrm{~b}-\mathrm{f}$ \\
\hline 'Zenith’ & $100 \mathrm{a}$ & 584 a & 1429 a & $30.2 \mathrm{ab}$ & $10.0 \mathrm{ab}$ \\
\hline 'Emerald' & 59 bcd & $177 \mathrm{c}$ & $686 \mathrm{bc}$ & $10.6 \mathrm{def}$ & $2.8 \mathrm{f}$ \\
\hline 'HT-210’ & $45 \mathrm{~d}$ & $170 \mathrm{c}$ & $685 \mathrm{bc}$ & $9.3 \mathrm{f}$ & $2.7 \mathrm{f}$ \\
\hline 'DALZ0101' & $76 \mathrm{bc}$ & $509 \mathrm{ab}$ & $1463 \mathrm{a}$ & $26.7 \mathrm{a}-\mathrm{d}$ & $6.9 \mathrm{~b}-\mathrm{e}$ \\
\hline 'Zeon’' & $39 \mathrm{~d}$ & $233 \mathrm{bc}$ & $1042 \mathrm{abc}$ & $11.5 \mathrm{def}$ & $4.5 \mathrm{~d}-\mathrm{g}$ \\
\hline Mascarene grass & $48 \mathrm{~d}$ & $158 \mathrm{c}$ & $548 c$ & $8.9 \mathrm{f}$ & $2.5 \mathrm{f}$ \\
\hline Japanese lawn grass & $71 \mathrm{a}$ & 376 & 1127 & $18.7 \mathrm{a}$ & $6.4 \mathrm{a}$ \\
\hline Fine-leaved zoysiagrass ${ }^{\mathrm{u}}$ & $53 \mathrm{~b}$ & 249 & 885 & $13.4 \mathrm{~b}$ & $3.9 \mathrm{~b}$ \\
\hline
\end{tabular}

${ }^{2} 1 \mathrm{~cm}^{2}=0.1550$ inch $^{2}$.

'Total length of four stolons/plot; $1 \mathrm{~cm}=0.3937 \mathrm{inch}$.

${ }^{x}$ Stolon growth rate was determined from 49 to 56 DAP

"Entries are sorted according to alphabetical order inside each species.

"Within columns, means followed by the same letter are not significantly different according to Fisher's protected least significant difference test at $\alpha=0.05$.

"Fine-leaved entries [leaf width $\leq 2 \mathrm{~mm}(0.08$ inch $)$ ] were 'Emerald', 'HT-210', 'DALZ0101', 'Zeon', and mascarene grass. 
intervals did not overlap. Nonlinear regression analysis of the turf cover data were performed using GraphPad Prism (version 5.00 for Windows; GraphPad Software, La Jolla, CA).

Data were analyzed using PROC ANOVA, PROC TTEST, and PROC REG (SAS version 9.2; SAS Institute, Cary, NC). When differences were examined between species, 'Emerald' and 'HT-210' (hybrid zoysiagrass) and mascarene grass were grouped within fine-leaved zoysiagrass because of their similarities in color, texture, and density with respective species. Means were separated using Fisher's protected least significant difference when $\mathrm{F}$ tests were significant at $\alpha=0.05$.

\section{Results}

The establishment rate at the beginning of trial was very low, influenced by low air temperatures (Fig. 1). Turf coverage was significantly $(P<0.001$ on 35 DAP; $P<0.05$ on 70 and 140 DAP) affected by genotype during the establishment of the study (Table 2). At 35 DAP, 'Zenith' and 'El Toro' had the highest coverage (100 and $81 \mathrm{~cm}^{2}$, respectively), while coverage of mascarene grass, 'Meyer', 'HT-210', and 'Zeon' ranged from 48 to $39 \mathrm{~cm}^{2}$ (Table 2). At $70 \mathrm{DAP}$, coverage ranged from 584 to $158 \mathrm{~cm}^{2}$ ('Zenith' and mascarene grass, respectively), while at the last observation on 17 Oct. (140 DAP) 'DALZ0101', an advanced selection of manilagrass, along with 'Zenith', had more turfgrass coverage, although they were far from achieving full plot cover at the end of the first growing season. On 17 Oct., coverage ranged from 1463 to 548 $\mathrm{cm}^{2}$. 'Emerald', 'HT-210', 'Meyer', and mascarene grass had the lowest coverage at the end of the growing season. In this study, differences between japanese lawn grass and fineleaved zoysiagrass genotypes were not significant, except at 35 DAP $(P<0.05)$.

Significant differences were observed $(P<0.001)$ in total stolon length and stolon growth rate among the genotypes (Table 2). Total stolon length at 56 DAP ranged from 8.9 to $30.2 \mathrm{~cm}$ and stolon growth rate ranged from 2.5 to $10.0 \mathrm{~cm}$ per week (by mascarene grass and 'Zenith', respectively, for both parameters). For all stolon growth parameters, japanese lawn grass, as species, had higher total stolon length and growth rate compared with manilagrass $(P<0.05$ and $P<0.01$, respectively). Genotype rankings were similar between top coverage and total stolon length, although some exceptions existed.

Analyzing the morphological traits of stolon/rhizome (Table 3), 'El Toro' had the largest diameter and, as well as 'Zenith', the highest internode length. Mascarene grass, one of the slowest establishing entries in the study, had higher stolon/rhizome density of $4.31 \mathrm{~cm} \cdot \mathrm{cm}^{-2}$, similar to 'Emerald' $\left(3.27 \mathrm{~cm} \cdot \mathrm{cm}^{-2}\right)$, while 'Meyer' was lower $\left(1.22 \mathrm{~cm} \cdot \mathrm{cm}^{-2}\right)$. Japanese lawn grass in our study produced significantly thicker $(P<0.001)$ and longer
$(P<0.01)$ stolon/rhizome internode ( $1.07 \mathrm{~mm}$ and $1.74 \mathrm{~cm}$, respectively) than fine-leaved group $(0.85 \mathrm{~mm}$ and $1.30 \mathrm{~cm}$, respectively) but had a lower stolon/rhizome density (1.86 vs. $3.02 \mathrm{~cm} \cdot \mathrm{cm}^{-2}$ ). Weak stolon/rhizome dry biomass differences were not significant among the entries and ranged from 0.0313 to $0.0438 \mathrm{~g} \cdot \mathrm{cm}^{-2}$.

Environmental conditions during fall and winter were not severe (Fig. 1), compared with the last 20 years average; thus, some genotypes did not completely lose color during winter. Besides, newly established turfs usually exhibit better winter color retention than mature surface (Sifers et al., 1992b). Zoysiagrass entries $(P<$ $0.001)$ and species $(P<0.001)$ significantly affected green turf color retention. The sigmoid models provided a representative fit of the data to describe the dynamics of the color retention (Figs. 2 and 3), resulting in average $R^{2}$ values of 0.95 . The average number of days for the entries included in the study to reach $50 \%$ green cover was 72.7. 'Zenith' and 'Meyer' exhibited the lowest color retention, retaining $50 \%$ green color at 33.9 and 37.1 Days 50 . A distinct trend was observed in this study on winter color retention of genotypes, as measured by days to $50 \%$ color retention, among zoysiagrass species. Differences in between japanese lawn grass cultivars were observed, with 'DeAnza', 'El Toro', and above all, 'Victoria' (57.2, 57.8, and 77.6 Days 50 , respectively) that retained green color better than 'Meyer' (37.1 Days50). However,

Table 3. Biometric traits of zoysiagrass cultivars and species evaluated on 1 Nov. 2006.

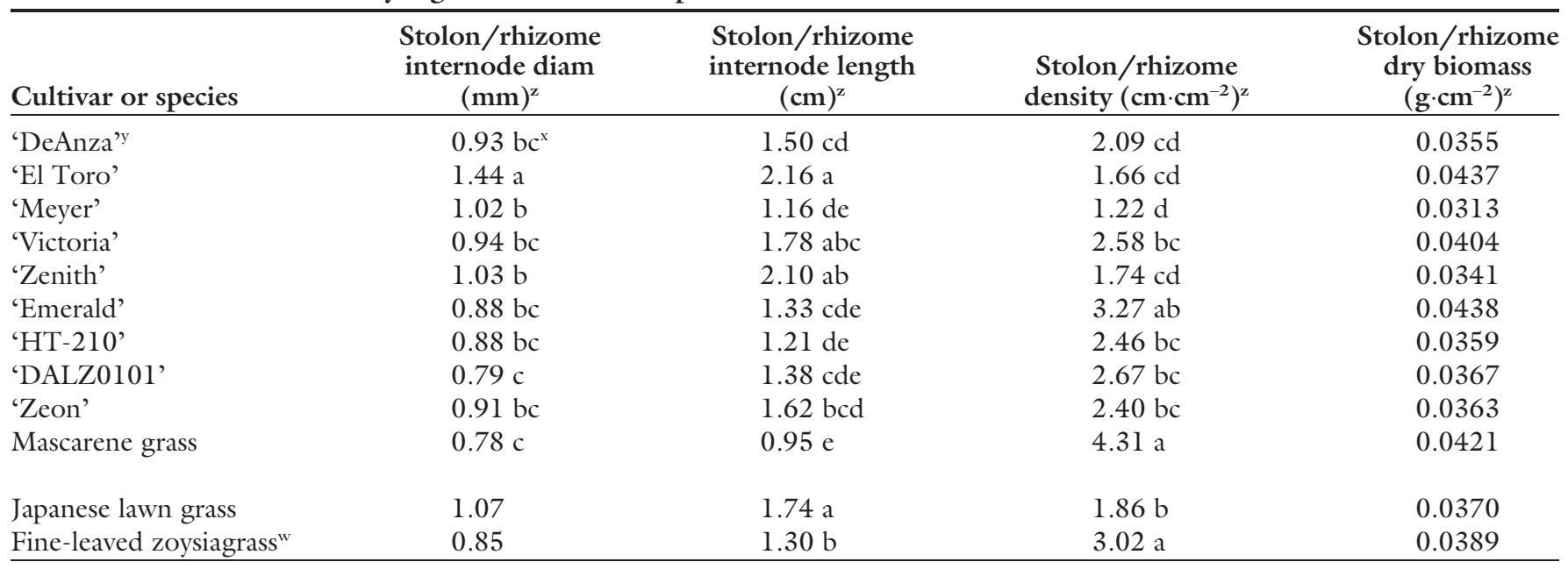

${ }^{\mathrm{z}} \mathrm{l} \mathrm{mm}=0.0394$ inch, $1 \mathrm{~cm}=0.3937 \mathrm{inch}, \mathrm{l} \mathrm{cm} \cdot \mathrm{cm}^{-2}=2.5400$ inches $/$ inches ${ }^{2}, \mathrm{l} \mathrm{g} \cdot \mathrm{cm}^{-2}=0.2276 \mathrm{oz} /$ inch $^{2}$.

'Entries are sorted according to alphabetical order inside each species.

${ }^{x}$ Within columns, means followed by the same letter are not significantly different according to Fisher's protected least significant difference test at $\alpha=0.05$.

"Fine-leaved entries [leaf width $\leq 2 \mathrm{~mm}(0.08$ inch $)$ ] were 'Emerald', 'HT-210', 'DALZ0101', 'Zeon', and mascarene grass. 


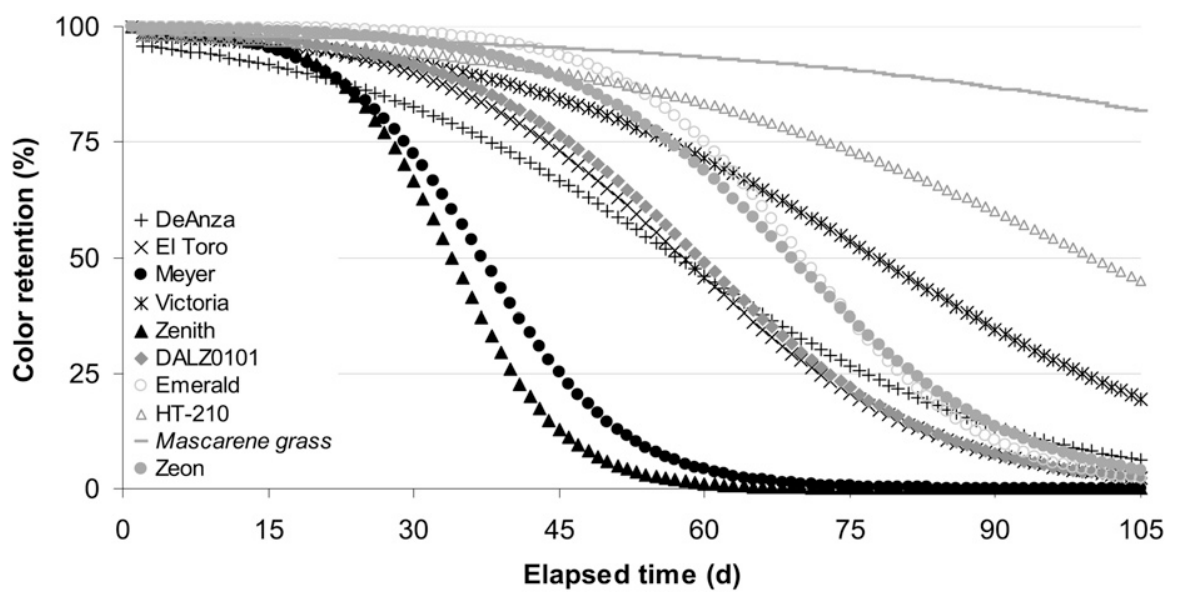

Fig. 2. Predicted winter color retention curves for zoysiagrass cultivars and species.

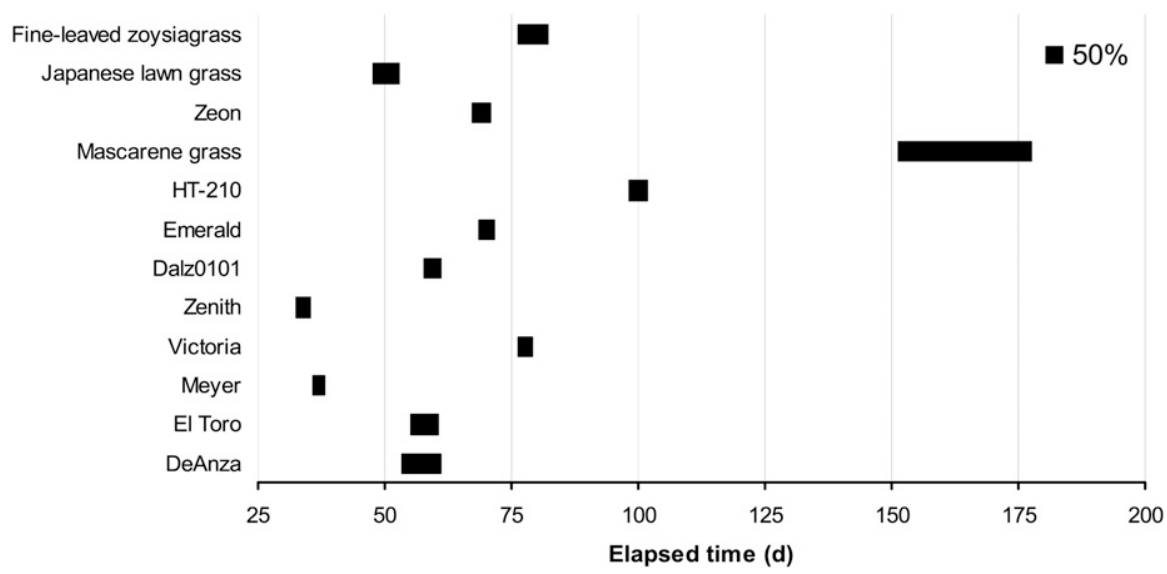

Fig. 3. Confidence intervals (95\%) for the mean number of days after 17 Oct. that zoysiagrass cultivars and species retain $50 \%$ green cover during Fall-Winter 200607. Pairs of means are significantly different $(\alpha=0.05)$ if their confidence interval bars do not overlap. Fine-leaved entries [leaf width $\leq 2 \mathrm{~mm}(0.08$ inch $)$ ] were 'Emerald', 'HT-210', 'DALZ0101', 'Zeon', and mascarene grass.

japanese lawn grass exhibited poor color retention (50.3 Days 50 ) compared with fine-leaved zoysiagrass genotypes (79.3 Days 50 ).

\section{Discussion}

Coverage was affected by genotype, but the overall effect of the species was not always evident. While there were statistical differences between cultivars, differences among species existed at $35 \mathrm{DAP}$ but not at 70 and $140 \mathrm{DAP}$. It is in contrast to recent reports (Patton et al., 2007), clearly because the high variability between replicates weakened the patterns previously observed. The performance of 'Zenith' confirmed that this commercially available seeded genotype has an excellent growth rate, which was in accordance with previous studies (Patton et al., 2007). a key morphological features directly correlated to the aesthetic pleasing and functional quality of the surface. Significant differences in stolon/rhizome dry biomass were not observed at the end of the growing seasons, although other differences in biometric traits were detected. This discrepancy possibly occurred because of the increased variability between plots. Stolon development and morphological traits are important factors because soluble carbohydrates are stored in these organs and they relate to the performance and stress response to biotic and abiotic stresses. Besides, propagation with plant material of decreased vigor might retard the time to reach full establishment. Usually growth rate reflects stolon growth rate, although some results may be atypical because of differences in number of stolon and rhizomes produced between genotypes, as well as different behavior in colonizing (production of secondary stolons and rhizomes).

Breeders' efforts were evident analyzing the japanese lawn grass cultivars, focused on enhancing the growth rates and winter color retention. 'Meyer' is considered an industry standard because it has been widely used since the 1950s, and it produced less coverage 140 DAP $\left(558 \mathrm{~cm}^{2}\right)$ than newer released cultivars of japanese lawn grass. 'DeAnza', 'El Toro', and 'Victoria' were released by University of California, Riverside, and the breeding program that developed 'DeAnza' and 'Victoria' was specifically aimed at selecting grasses that had superior winter color retention characteristics when compared with all other commercially available cultivars (Gibeault et al., 1997). In this study, this trait was confirmed, as well as differences between 'Victoria' and 'El Toro', that were in agreement with a previous report (Cockerham et al., 1997) that compared 'DeAnza' and 'El Toro'. The two newer cultivars are siblings, but 'DeAnza' is quicker to establish than 'Victoria'. Both are reported to respond to fertilizer treatments with improved green color retention, in particular 'DeAnza' to nitrogen (Gibeault et al., 1997). Comparing the three most widely used cultivars, 'Emerald', a hybrid between japanese lawn grass and manilagrass that is well adapted in acidic soils, showed better performance than 'El Toro' and 'Meyer', according to a previous report (Sifers 
et al., 1992b). Under temperate climatic conditions such as coastal areas of Mediterranean basin, mascarene grass showed acceptable green color quality throughout the year of the present study.

It is interesting to correlate the color retention's result to the fact that japanese lawn grass generally exhibited less winter injury in the field and better freeze tolerance than manilagrass (Patton and Reicher, 2007). It is possible to confirm that japanese lawn grasses, with higher freeze tolerance, have lower winter color retention, as a result of a faster entrance into dormancy compared with manilagrasses when low temperatures occur, suggesting an improved cold acclimation mechanism during the autumn.

\section{Conclusions}

This study indicates that considerable differences exist between zoysiagrass genotypes in establishment rate, morphological traits, and winter color retention. For several decades in the United States, 'Meyer' has been the principal cultivar used, but its limited growth rate and winter color retention were also confirmed by this study, and they have restricted its widespread use. In this study, new cultivars have provided faster establishment rates and shorter dormant period. Under the conditions of this study, with moderate winter temperatures, the value of overseeding may not be worth the economic costs of reduced turf quality, particularly true for fine-leaved genotypes. These results will promote golf and sports managers in selecting cultivars of zoysiagrass that have a high establishment rate and acceptable winter color retention in the temperate Mediterranean area. On the other hand, selecting a genotype with low growth rate not only will be acceptable for lawn and municipal surfaces but will also help to reduce equipment wear, labor, and fuel costs associated with maintaining the surface.

\section{Literature cited}

Anderson, S.J. 2000. Taxonomy of Zoysia (Poaceae): Morphological and molecular variation. PhD Diss., Texas A\&M Univ., College Station.

Beard, J.B. 1973. Turfgrass: Science and culture. Prentice Hall, Englewood Cliffs, NJ.
Busey, P. and B.J. Myers. 1979. Growth rates of turfgrasses propagated vegetatively. Agron. J. 71:817-821.

Carroll, M.J., P.H. Dernoeden, and J.M. Krouse. 1996. Zoysiagrass establishment from sprigs following application of herbicides, nitrogen, and a biostimulator. HortScience 31:972-975.

Cockerham, S.T., V.A. Gibeault, S.B. Ries, and R.A. Khan. 1997. Verticutting frequency and mowing height for management of 'DeAnza' and 'Victoria' zoysia. Intl. Turfgrass Soc. Res. J. 8: 419-425.

Croce, P., A. De Luca, M. Mocioni, M. Volterrani, and J.B. Beard. 2001. Warmseason turfgrass species and cultivar characterizations for Mediterranean climate. Intl. Turfgrass Soc. Res. J. 9:855-859.

Daniel, W.H. 1955. Zoysias for midwest lawns, p. 34. In: Proc. Midwest Regional Turf Foundation Conf. Midwest Regional Turf Foundation and Dept. Agronomy, Purdue Univ., West Lafayette, IN.

De Luca, A., M. Volterrani, M. Gaetani, N. Grossi, P. Croce, M. Mocioni, and F. Lulli. 2008. Warm season turfgrass adaptation in Europe north of the $45^{\circ}$ parallel, p. 496-501. In: D. Crews and R. Lutz (eds.). Science and golf V. Energy in Motion, Mesa, AZ.

Diesburg, K.L. 2001. Improvements in zoysiagrass. Golf Course Mgt. 69:7277.

Du, H., Z. Wang, and B. Huang. 2008. Differential responses of tall fescue and zoysiagrass to heat and drought stress. Acta Hort. 783:207-214.

Dunn, J.H. 1991. Establishing zoysiagrass: Speeding establishment rates is important for increased acceptance of zoysiagrass as a golf course turf. Golf Course Mgt. 59:38-52.

Dunn, J.H., D.D. Minner, B.F. Fresenburg, and S.S. Bughrara. 1993. Fall fertilization of zoysiagrass. Intl. Turfgrass Soc. Res. J. 7:565-571.

Erusha, K.S., R.C. Shearman, and L.A. Wit. 1999. A device to measure turfgrass load bearing capacity under field conditions. Crop Sci. 39:1516-1517.

Forbes, I. 1962. Registration of 'Emerald' zoysiagrass. Crop Sci. 2:533-534.

Forbes, I. and M.H. Ferguson. 1947. Observations on the Zoysia grasses. Greenkeepers Rpt. 15:7-9.

Fry, J.D. and P.H. Dernoeden. 1987. Growth of zoysiagrass from vegetative plugs in response to fertilizers. J. Amer. Soc. Hort. Sci. 112:286-289.
Fry, J.D., M. Kennelly, and R. St. John. 2008. Zoysiagrass: Economic and environmental sense in the transition zone: Zoysiagrass fairways require fewer inputs, which add up to fewer dollars and better environmental management. Golf Course Mgt. 76:127-132.

Gibeault, V.A., S.T. Cockerham, R. Autio, and S.B. Ries. 1997. The enhancement of zoysia winter colour. Intl. Turfgrass Soc. Res. J. 8:445-453.

Higgins, J. 1998. Zoysiagrass lawns. Alabama Coop. Ext. System ANR-1129.

Hunt, W.F. and H. Wen Cai. 1993. Turf development in Beijing, China. Intl. Turfgrass Soc. Res. J. 7:845-849.

Hurley, R.H. 2000. New goal for indoor soccer turf: Take it outside to tees, greens: Modular technology offers another choice in root-zone construction. Golf Course Mgt. 68:49-53.

Hurley, R.H., H. Yanagi, T. Yamada, M. Sasakura, and M. Tomita. 1989. Winter overseeding cool season grasses on dormant zoysiagrass (Zoysia spp.) turfs in Japan. Intl. Turfgrass Soc. Res. J. 6:431-436.

Karcher, D.E., M.D. Richardson, J.W. Landreth, and J.H. McCalla, Jr. 2005. Recovery of zoysiagrasss varieties from divot injury Appl. Turfgrass Sci. doi:10.1094/ ATS-2005-0117-01-RS.

Lang, G.A., J.D. Early, G.C. Martin, and R.L. Darnell. 1987. Endo-, para-, and eco-dormancy: Physiological terminology and classification for dormancy research. HortScience 22:371-377.

Leegood, R.C. 1993. Carbon dioxideconcentration mechanism, p. 47-72. In: P.J. Lea and R.C. Leegood (eds.). Plant biochemistry and molecular biology. Wiley, Chichester, UK.

Lyman, G.T., C.S. Throssell, M.E. Johnson, G.A. Stacey, and C.D. Brown. 2007. Golf course profile describes turfgrass, landscape, and environmental stewardship features Appl. Turfgrass Sci.doi:10.1094/ ATS-2007-1107-01-RS.

Marcum, K.B. and C.L. Murdoch. 1990. Growth responses, ion relations, and osmotic adaptations of eleven $\mathrm{C}_{4}$ turfgrasses to salinity. Agron. J. 82:892-895.

Marcum, K.B., M.C. Engelke, S.J. Morton, and R.H. White. 1995. Rooting characteristics and associated drought resistance of zoysiagrasses. Agron. J. 87: 534-538.

McCarty, L.B. 2001. Best golf course management practices. Pearson/Prentice Hall, Upper Saddle River, NJ.

Miele, S., M. Volterrani, and N. Grossi. 2000. Warm season turfgrasses: Results of 
a five-year study in Tuscany. Agricoltura Mediterranea 130:196-202.

Patton, A.J. 2007. Fertilizing your lawn. Univ. of Arkansas Coop. Ext. Service Agr. Natural Resources FSA2114.

Patton, A.J. and Z.J. Reicher. 2007. Zoysiagrass species and genotypes differ in their winter injury and freeze tolerance. Crop Sci. 47:1619-1627.

Patton, A.J., J.J. Volenec, and Z.J. Reicher. 2007. Stolon growth and dry matter partitioning explain differences in zoysiagrass establishment rates. Crop Sci. 47:1237-1245.

Pompeiano, A., M. Volterrani, F. Lulli, N. Grossi, and S. Magni. 2008. Zoysiagrass stolon activity during establishment. Proc. 1st European Turfgrass Soc. Conf. p. 149-150.

Richardson, M.D. and J.W. Boyd. 2001. Establishing Zoysia japonica from sprigs: Effects of topdressing and nitrogen fertility. HortScience 36:377-379.

Richardson, M.D., D.E. Karcher, and L.C. Purcell. 2001. Quantifying turfgrass cover using digital image analysis. Crop Sci. 41:1884-1888.
Sifers, S.I., J.B. Beard, and M.H. Hall. 1992a. Comparative establishment rates and initial performance characteristics of four commercially available zoysiagrass (Zoysia spp.) cultivars and four experimental selections for 1988 and 1989, p. 29-31. In: Texas Agr. Expt. Sta. PR-4986.

Sifers, S.I., J.B. Beard, and M.H. Hall. 1992b. Comparative characterizations of four commercially available cultivars and four experimental selections of Zoysiagrass (Zoysia spp.) for 1990, p. 31-33 In: Texas Agr. Expt. Sta. PR-4986.

Trappe, J.M., A.J. Patton, and M.D. Richardson. 2009. Clipping yield and scalping tendency differ for bermudagrass and zoysiagrass cultivars. Arkansas Turfgrass Rpt. 2008 56:153-157.

Trappe, J.M., D.E. Karcher, M.D. Richardson, and A.J. Patton. 2011a. Shade and traffic tolerance varies for bermudagrass and zoysiagrass cultivars. Crop Sci. 51:870-877.

Trappe, J.M., D.E. Karcher, M.D. Richardson, and A.J. Patton. 2011b. Divot resistance varies among bermudagrass and zoysiagrass cultivars. Crop Sci. 51:1793-1799.
Turgeon, A.J. 1991. Turfgrass management. Pearson Education, Upper Saddle River, N.J.

Unruh, J.B., L.E. Trenholm, and J.L. Cisar. 2006. Zoysiagrass in Florida. Florida Coop. Ext. Serv. ENH11.

Volterrani, M., N. Grossi, G. Pardini, S. Miele, M. Gaetani, and S. Magni. 1997. Warm season turfgrass adaptation in Italy. Intl. Turfgrass Soc. Res. J. 8:1344-1354.

Volterrani, M., N. Grossi, F. Lulli, and M. Gaetani. 2008. Warm-season turfgrass establishment by transplant of single potted plants. Acta Hort. 783:7784.

Wei, S., Y. Zhou, and D. Li. 2008. Cold sensitivity and biochemical adjustments in zoysiagrass under low temperature stress. Acta Hort. 783:195-206.

Youngner, V.B. 196la. Accelerated wear tests on turfgrasses. Agron. J. 53:217218.

Youngner, V.B. 1961b. Growth and flowering of Zoysia species in response to temperatures, photoperiods, and light intensities. Crop Sci. 1:91-93. 